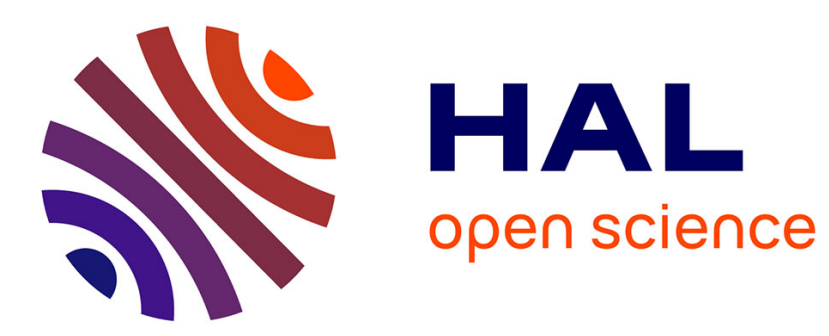

\title{
Revisiting Narrative Journalism as One of The Futures of Journalism
}

\author{
Erik Neveu
}

\section{To cite this version:}

Erik Neveu. Revisiting Narrative Journalism as One of The Futures of Journalism. Journalism Studies, 2014, 15 (5), pp.533 - 542. 10.1080/1461670X.2014.885683 . hal-01077847

HAL Id: hal-01077847

https://hal-univ-rennes1.archives-ouvertes.fr/hal-01077847

Submitted on 27 Oct 2014

HAL is a multi-disciplinary open access archive for the deposit and dissemination of scientific research documents, whether they are published or not. The documents may come from teaching and research institutions in France or abroad, or from public or private research centers.
L'archive ouverte pluridisciplinaire $\mathbf{H A L}$, est destinée au dépôt et à la diffusion de documents scientifiques de niveau recherche, publiés ou non, émanant des établissements d'enseignement et de recherche français ou étrangers, des laboratoires publics ou privés. 


\title{
REVISITING NARRATIVE JOURNALISM AS ONE OF THE FUTURES OF JOURNALISM
}

\author{
Erik NEVEU* \\ * CRAPE Centre de Recherches sur l'Action Politique en Europe UMR CNRS 6051
}

News-making and reporting are caught in a process of rationalisation which can be summarized in the injuction to produce fast, to write short and simple and to value useful news for audiences only interested by practical matters. This paper would firstly suggest that if this new style of journalism has produced interesting innovations, its costs are worthier debating than its contributions. It would then argue that mobilising the competitive advantages of a tradition of investigative and narrative journalism may be a reasonable bet to struggle against the news supplied by blogs, aggregators and short-format news sources. A third part suggests how this apparent "back to basics" involves however significant changes in both the training of journalists and the nature of the medium used for the diffusion of this renewed style of reporting.

Keywords: Books; Immersion Journalism; Journalistic Writing; Narrative Journalism, Social Sciences. 
"This abominable and voluptuous act called reading the newspaper, by which all the misfortunes and cataclysms of the universe during the last twenty four hours, the battles which took the lives of fifty thousands men, the crimes, the strikes, the bankruptcies, the fires, the poisonings, suicides and divorces, the cruel emotions of the statesman and actor, transmuted for our private use, for us who are not involved, into a morning delight, combine excellently, in a specially tonic and exciting way, to the recommended ingestion of a few mouthfuls of coffee with milk"

Marcel Proust (1923)

Warnings have been launched. Obituaries have been prepared. Even conferences were organised. The news was sad: journalism was dying. In the best cases its life chances were dubious. Editors, scholars and heads of journalism schools have developed their explanations and diagnoses of the current crisis. Journalism is facing today a most complex combination of challenges (Neveu, 2010). It goes from the institutionalisation of job insecurity for its practitioners, to the blurring of the border between professionalism and amateurism, fact-checking and comments on rumours (Kovach \& Rosenstiel, 2011), without forgetting the declining support of the younger generations to the idea that news is something worth a few pounds or euros a week.

The aim of this contribution is to highlight one of the opportunities for a new momentum for journalism. Among the major reasons of the current crisis is a double process of rationalisation, which could also be deciphered as a double process of impoverishment, of disconnection of journalism with a significant part of the readership's expectations and abilities. On the one hand this rationalisation has targeted the lay-out and templates of the press. To face the growing competition from television and websites, editors and consultants have developed mimetic imitations of the screens on the printed page. Many studies on the "form of news" (Barnhust \& Nerone, 2002; Broesma, Ed, 2007) suggest a process of rationalisation and clarification of the lay-out since the end of the $19^{\text {th }}$ century, expressed in a more visible organisation of the newspapers into specialised news-sections, in clearer visual distinction among the articles structuring each page. The moves toward shorter formats, the replacement of long verbatim quotations by compact sound bites (Hallin, 1994) or interpretive commentaries (Schudson, 1982) are also well-documented trans-national trends. The recent downsizing of the newsrooms with its reduction of the number of journalists dedicated to specialised news-beats (labour, international...) has strengthened these evolutions. More and more papers are produced by less specialised journalists, invited to express their professional skills in the double-binding art of making sense of a more and more complex world in shorter and shorter formats. On the other hand rationalisation has had a strong impact on the contents of the press too. The number of news-sections was often reduced to those considered as more reader-friendly, as maximising audiences or channelling significant amounts of advertising. A publisher's memo argues that the Miami Herald would "focus its newsroom 
resources on nine subject areas that the readers have told us are especially important and useful: local government; education; sports; environment, consumer news, Florida news, Latin America. Health/medicine and Crime" (Cook, 1995: 173-4). Such a redefinition of the "useful" topics worth significant coverage mirrors the trend towards what has been coined as "journalism of communication", by the researchers of the Canadian University Laval (Brin, Charron, de Bonville, 2004). In such a role-definition (which is not completely different from what Eide and Knight -1999- describe in Norway as "service journalism") the challenge of journalism is to reach of audiences overwhelmed by floods of communications. The good journalist combines humour, closeness and usefulness to conquer the audience's attention. He/she is no longer firstly in charge of making sense of the working of the polity or of geopolitical stakes. She/he is a mediator, guiding and counselling audiences made of consumers in quest of good bargains, pleasant entertainments, useful advices on one's health management or financial investments. Even questioning which politician should deserve one's vote may be seen as contributing to rational consumerism. This journalism can be useful and even the critical sociologist may be happy to read a good column on cooking or travelling, to discover in a magazine a useful website. But the price of this service journalism is what the French liberal Philosopher Benjamin Constant described two centuries ago as the paradox of the "freedom of the modern": we can live in a society whilst forgetting than there is such a thing as a society.

The result of this double process of rationalisation as a combination of compact and useful news processing is nowhere more visible than in the free newspapers (Metro, 20 Minutes) which are today market leaders in many European countries (Rieffel, 2010). They supply in a light tabloid format a highly selective, highly condensed coverage of the news. The balance among news-section values a significant attention to sports, lifestyles and consumer service. But such an evolution is not the monopoly or the press. The French TV channel $M 6$ - struggling to gain its consecration as one of the major networks made the strategic choice of broadcasting news bulletins reduced to six minutes air-time.

This paper will develop a three-fold reflection on those trends. It will suggest in a first part that, if this new style of journalism has produced innovations, its costs are worthier debating than its contributions. It would then argue that something like a return to the comparative advantages of a tradition of investigative and narrative journalism may be a reasonable bet to struggle against the news supplied from blogs, aggregators and short-format news sources. In a third part, I would argue that the paradox of this apparent "back to basics" is the need for significant changes in both the training of journalists and the nature of the media used for the diffusion of this redefined products of journalism.

\section{Light news, Heavy costs.}

The success of the free newspapers invites to go beyond the nostalgia of an imaginary golden age when an enlightened citizenry would have massively read the best of the broadsheets and felt a passionate commitment 
for public affairs. One cannot make sense of the success of these lightweight newspapers just by a depreciative description as "McPapers". Their editors and journalists invented a style of newspapers which fits with the habits of millions of people having thirty minutes to browse news when they are commuting. They have developed a skilled use of computer graphics and maps, processing complex data into clear visual representations. The old motto of the French newsrooms, "Ecrire pour son lecteur" (To write for one's reader) has probably be taken more seriously, transforming what was often lip service into a more conscious anticipation of the readers' tastes, more probably into real attention to the audience's wishes as defined by marketing and RD departments. In France the free dailies have been able to channel significant audiences back into newspaper-reading. An issue of Le Monde costs 2 euros [1], a price often beyond the reach of students and working class readers. The very short, dispatch-style, format of articles also satisfied those among the potential readers who felt that too many news-sections looked as made by specialists speaking to specialists, or that the French style of journalism wad giving too much weight to journalists opinions and comments. Brevity and condensation were thus perceived as producing a crystal clear text, leaving the readers free to produce their own conclusions and evaluations. The free dailies have also been a laboratory of convergence, developing among their staff skills of translators, instantly converting a paper into web pages or even TV footage.

But developing a balance sheet of this rationalization suggests the question "what has been lost or weakened?" As the focus of this paper is the final product of the journalists' work we would pay attention to changes which had a significant impact on the nature of the news.

The downsizing of news-rooms has produced a more "seated" journalism, using more computer terminals and phone contacts than investigating and ferreting out with old style "legwork". This trend is especially visible for the free newspapers with smaller staffs, depending more on the recycling (Rébillard, 2006) and editing of press agency reports. Such changes mean less oportunities for in-depth investigation, less time for experiencing the "flesh", flavours and scenes of the news. These changes also create more layers of mediation (phone, reading of reports, commenting from images seen on a TV screen) between the actors of events and the journalists. They are less direct news gatherer, more "processsors" to use Tunstall' typology (1971). The quarters of modern journalism facing the strongest commercial pressures are less and less in situations where it could express a basic claim such as "I was there, I saw it, I met them". The stake goes beyond trustworthyness. It questions the kind of narrative production which flees beyond the reach of this journalism. How to portray characters whom one never met directly [2]? How to describe spaces and actions only viewed on the blurred images of a computer or summarized in a dispatch? Paradoxically, the risk of producing fiction may be here stronger than when exploring the frontier between reporting and literature....

The compulsory use of very short formats creates multiple challenges. The Japanese art of the haïku suggests that inventing subtle, moving or impressive images and meanings is possible even in short texts. But writing good haikus is difficult. And making sense of the crisis of subprimes, of the 
chaos in Congo or of the solutions to fix a national pension system is probably even harder that communicating the emotion triggered by cherrytrees blossoming. If journalists working for web-sites or free newspapers may have enhanced the old journalistic art of explaining complex facts in a limited time or space, there are objective limits even to the most gifted practice of condensing facts and explanations. In French the same adjective "clair" expresses the idea of something bright or unambiguous, but also the idea of something lacking of depth or content (a thin soup = une soupe claire). Compact format journalism cannot really supply to its reader both a compact and edible summary of the news that one can read during a short tube journey, and an in-depth approach. The question of depth goes beyond the idea of complex or multi causal explanations. Depth could also mean portraying characters with some precision, showing the practical impact of a policy choice on its targets, brushing the cityscapes or highlighting the material background of an event. One could argue that if the audience wishes more explanations, it could search it in specialised media or websites. But would such a quest often be done? And what would one think of a teacher or friend who would claim as a virtue of being always simplistic?

The final limit of the new style of news-coverage could be linked to the question of pleasure. The use of narratives, the art of storytelling are not sins or treasons for the journalistic practice. Writing or telling seamless, attractive and illuminating stories is a core skill to transform facts into news. Darnton gives (1975) an illuminating example of this process when he writes on his early experience as a reporter, how he learned to produce a colourful story from the routine fact of a stolen bike. Reading the news is also an opportunity to enjoy stories, to discover unknown social worlds, to combine the understanding of the "true" world with an effortless trip in a narrative flow. Is it possible to provide such gratifications with the new press and media templates? One of the great contributions of the "reception studies" has been to provide the empirical proof of the huge variety of receptions, uses and gratifications of the media messages. Claiming that there is one best way to satisfy all news consumers has no sense. The feeling of keeping in touch with the world at the cost of ten to twenty minutes of reading a free newspaper or browsing at a screen can be gratifying. But Proust's quotation suggests other pleasures. Are such "voluptuous" readings the privilege of a leisure-class of highly educated readers? Or are just such effects beyond the reach of 1800 signs papers dressed in the straightjacket of a vocabulary impoverished by the obsession of simplicity?

\section{Rehabilitating the Art of Narrative Reporting}

The current trends in journalism are paradoxically devaluating some of the strongest and most peculiar resources of the profession. Fighting against screens with the resources of the screen is a battle which can only be lost. Journalism has accumulated a huge legacy of skills in investigation and data collecting, in fact checking and news processing. Its spirit is also transforming facts into attractive stories. To use a phrase borrowed to the vocabulary of economics, journalists should use their "comparative 
advantages". What can journalists do better than most of their newsproducing competitors? As long as they have time and money enough, they usually make better investigations than most of bloggers and amateurs, as they would probably have accumulated a network of connections with sources, skills for data gathering and fact-checking. Computers and mobile phones allow access to many sources and data. But traditional "legwork" remains one of the bases of journalistic practice to meet and question actors and authorities, to gain a practical knowledge of the places and atmospheres. Conover writes, in his splendid reporting on the lives of illegal Mexican farm-workers in the USA:

"the truly meaningful things about a people are not learned by conducting an interview, gathering statistics or watching them on the news, but by going out and living with them. To get to know the Mexicans you need to speak their language, be willing to put up with living conditions less comfortable than our own..." (1987, xviii).

Conversely it is rare to see such activities developed by most of those who claim to the position of news-producers on the web. They are recycling and commenting facts, often rumours, rarely producing first hand reports.

Journalism is also a narrative art. The beliefs concerning the shrinking and rapidly collapsing attention levels of audiences, the processing-power of computer graphic to digest in graphs or maps complex data have converged to develop innovations in brevity. The style - if any- of modern journalism appears as the narrative equivalent of the skills of the Jivaro head-shrinkers. Such competence is useful, but the art of reporting has an opposite dimension. It means using the narrative dimension of the "once upon a time..." It means bringing audiences in hidden, unknown or surprising places and finding the words to express their peculiarities. Such challenges can hardly be faced using only the few hundred words of greyish, simple and basic vocabulary which are supposed to be the limit of audiences' linguistic abilities. Telling news as (true) stories also means organising a cast of characters, structuring a plot, mobilising audiences in a subtle use of the events and surprises in which lives are enfolded and unfold. Such a narrative journalism is in a structural opposition to the current trends of the profession. It values legwork and investigation when journalism is more and more an art of processing data supplied by official sources. It claims space to develop stories when the dominant pattern is to process many facts into small formats. It borrows from literature its writing techniques, from social sciences their investigative tools and interpretive methodologies when narrative in contemporary journalism has surrendered to the news-flash, and in-depth investigation to speed.

Describing this opposition is not building a great divide. A journalism helping its audience to behave like better informed consumers, a journalism mobilising computer-graphics explaining the why of an electoral landslide, of a financial bubble is praiseworthy. Conversely narrative reporting can also be crammed-up with clichés and prejudices, when an editor tells to a young reporter covering urban riots: "Find me a black, a beur and a dealer" [3](Champagne, 1993) as if this trio encapsulated the life of a city he never visited. Narrative reporting remains however a major opportunity for 
tomorrow's reporting as it creates a space where professionalism makes a huge difference with the "bricolage" of the continuum of "pro-amateur" news producers. Journalism as always been a practice of the ephemeral; it slips into the disposable. Longer narrative reporting could produce a "lasting journalism". If the phrase sounds like an oxymoron, let's speak of "legitimate" (Bourdieu, 1979) or "interpretive" journalism. Why is it possible to find books collecting the papers -sometimes half a century old or morefrom Joan Didion, Vassili Grossman, or Ryscard Kapuscinski, from Albert Londres, and Tom Wolfe? Why is it possible still enjoying them? Sometimes it comes from their style. More often they give the feeling to make sense of issues, trends and events which remain meaningful. And which journalism successfully faces this test of time? Almost always texts belonging to narrative, investigative and explanatory reporting....

Pleading for this alternative style of journalism may look like a blueprint produced by an academic far from the life of newsrooms. Eppur, si muove ! Robert Boynton (2005) has coined as "new-new journalism " the development of such reporting in the USA. A whole generation of journalists is exploring a style of reporting indebted to the "new journalism" of the sixties, though less narcissistic in its mood, less pyrotechnic in its writing. This generation of journalists can be defined by four common denominators. They practice long and in-depth investigation, sometimes risky ones: twelve years of relationship to a poor Puerto-Rican family for Adrian Nicole Leblanc (2004), eight years following and deciphering a complex case in a Massachusetts court for Harr (1995). Junger (2010) shared during months the experience of an infantry platoon in Afghanistan. The phrase "immersion journalism" used by some of these reporters is illuminating. A second feature of this journalism is the aim to combine the objectivity, the factuality of the scenes and actions and the greatest attention to the subjective dimension of the experience and feelings of the actors of the events. To reach this goal and here is a third peculiarity- many journalists are mobilising tools borrowed from social sciences. Many among them have studied history, anthropology, sociology. They import techniques of data gathering, the use of scientific journals and all that ethnographic or sociological methods of interview and observation can bring for understanding groups sometimes socially very different from the investigator. Let's mention finally that this reporting, often combining magazine papers into books, is deeply narrative. It tells stories, it solves puzzles. It transforms its readers into travellers in the backstage of the social world. It organizes its narratives around a sophisticated cast of characters. Such style of reporting is not surprising in the USA where it mobilises a tradition (the muckrakers, Liebling and Mitchell, the "new journalism") and a whole range of magazines as niches for such contributions. What is more promising is the fact that such journalism develops in many countries (Bak \& Reynolds, 2011). The Belarus Svetlana Alexievitch wrote deeply moving reports on Chernobyl or on the Soviet veterans from the Afghanistan war (1992). This journalism finds an echo in India with the reports of Arundhati Roy (2011) on the policy of dam building and its ecological impact, or about the Naxalite movement. In France, where this style of journalism seemed to belong to the past, it gained a new life with the quarterly magazine $X X I$ selling after five years of existence more than 
60000 copies of each issue, when no one among the specialists in the press business would have bet on its survival beyond two years. The report of Florence Aubenas (2011), telling her immersion among the poor and precarious night-cleaners became a best-selling non fiction book.

\section{Redefining Journalistic Training and Mediums}

If a more narrative, more investigative reporting is one of the future of journalism, which are the implications of this opportunity?

The first ones are concerning the training of future journalists. In times of crisis schools of journalism have been competing to supply the newsrooms with the most "operational", "efficient" newcomers. A good graduate from a journalism school must be able to produce immediately material publishable without too much editing, he/she must be able to work for very different media. This training policy focused on the practical skills, the use of computer software, an art of hyper compact-writing. But the other side of the attention to these useful skills has often been new forms of antiintellectualism. Ruffin's testimony (2003) on his experience in one of the best French journalist schools - where the library could be closed for months without triggering any protest- gives a chilling example of these trends. Reluctance for "theory" would be understandable if the suggestions were to transform journalists into surrogate sociologists, or to cram-up reports with quotes from Weber or concepts from Parsons. But a clever journalistic use of social sciences would be something else.

Firstly ethnography and sociology supply a rich tool-kit of methods for observation, investigation, reflexive understanding of what is trustworthy or not in the data collected by legwork. Secondly they provide interpretive tools. Theories may be use to intimidate or to bore audiences. They can also suggest the schemes which would allow making sense, in simple words, of complex causal relations. A social science training also teaches how to do data-mining on the web, where to locate real specialists on many social issues. It allows too to gain a panoptic vision of scientific journals and publishers where the most trustworthy and recent state of knowledge can be found. Lawrence Wright explains that he starts all his investigative work by research on Lexis-Nexis; Eric Schlosser argues "My research process is to start reading secondary sources. Then I move to academic journal articles. Then I move to trade journals. I don't call anyone up until I've done an enormous amount of reading on the subject" (Boynton, 441-2, 350).

Last but not least, the social sciences - "reception studies" would be pivotal here- can help understanding the audience expectations, their perception logics. Marketing services behave as if ventriloquists of audiences' wishes, even if their real knowledge of these expectations is dubious (Brandewinder, 2009). One of the problems of journalism may have be to pursue after an imaginary public. Anticipating the supposed reader's desires is too often an invitation to restrain ambitions, to think of audience in a kind of newsroom "third person effect" where audiences are "less": less clever, less curious, less reflexive that the news-professionals. Being a good editor means thus providing the audience with shorter papers, simpler analysis 
and entertaining newsbeat...a policy which is more efficient at cutting costs than boosting audiences. Conversely the few studies exploring the reception of narrative reporting in the press (Johnston \& Graham, 2012), and media (Machill, Löhler and Waldhauser, 2007) suggest that such framing improves understanding and memorization of news. Policies can be explored from the point of view of those who experience their impacts. Hot issues like immigration, the underground drug business... but also the worlds of finance or environmental issues could be, have been treated in readable and exciting ways by the "new-new" journalism. Would it be "populist" suggesting that providing working class audiences with stories which speak of their lives, mirror their experience with empathy and respect could be - even from a businesslike point of view- a strategy able to regain sales and attention?

Another redefinition of the journalists training should be re-evaluating writing abilities. Expressing much in a few words must remains part of the journalist skills. But the sad state of journalism may also come from the devaluation of other styles of writing, from the divorce with literature as a proof of seriousness and readability. If the real strength of journalism were to be "un-pure", always blurring its frontiers with social science and literature? Telling stories and portraying, inventing illuminating metaphors and playing with adjectives, combining empathy and distance to make sense of the beliefs and behaviours of those different from the reader are also the arts of journalism. Breslin's interview of the man who dug JFK's grave, Londres' report on the horrors of the Devil's island French penitentiary or Wallraf's undercover investigation on the Turkish Gastarbeiter in the 80's Germany- received enormous praise and resonance. Was it because they were made of short sentences? Or was it thanks to their expressive skills and narrative qualities?

Considering seriously the future of a narrative journalism invites to think of its medium. In many of the countries where this journalism has gained a significant recognition, its main expression comes from magazines (Granta, The New Yorker, Esquire, XXI). The decreasing importance of youth in their audience and the choice of Rolling Stone to reduce the length of the papers have questioned the future of these magazines. Will they survive the supposed reducing attention span of the new generations (Scherer, 2002)? This decreasing attention looks more like a myth (Newman, 2010) than a documented fact. As the global leisure time is not decreasing in developed countries, the problem is probably different. If the readership of some magazines crumbles, it is not because long articles are beyond the reach of internet zombies, but because the supply of leisure and cultural activities is endlessly increasing, fragmenting audiences, as is the case for TV networks. The right media strategy is thus to multiply the niches, mediums and templates to extend the supply of narrative reporting. Magazine reports would find new readers when available on the screens of iPads and tablets.

Books are not the first medium that common sense links to journalism. And moreover a significant number of major contributions to narrative journalism have reached a large audience as books. In the USA a book version is quite often the result of the upgrading and rewriting of reports originally published in magazines. In France, prominent contributors 
to this style of reporting have made the choice to go straight to the books. Such is the case of Jean Hatzfeld for a much praised trilogy on the Rwandan genocide. Significantly, all the French magazines publishing this style of reporting (XXI, Feuilleton, Muse) are only sold in bookshops, not with the press, suggesting the hybrid status of these publications, sometimes identified as "mooks". Combining -not converging- media could also mean, as Junger did during his fieldwork in Afghanistan, working with a cameraman and shooting a video film, producing then papers, a book and a documentary movie. Narrative journalism combines with very different templates. Sunday supplements, magazines and books will host the longest articles. But expressing the results of in depth investigations with attractive narrative style fits as well with the full page portrait, the double page report which takes a growing importance in the editorial menu of many dailies or web sites.

The future of journalism has no "one best way". As Downie and Schudson (2009) suggest, multiple initiatives and a strong journalistic imagination would be needed. Developing investigative-narrative journalism is one of the opportunities for renewal. The objection is often that it could only be a small niche activity, produced for a limited and culturally privileged audience. It would be foolhardy to suggest that this journalism would be tomorrow the core output of the profession. But the elitist objection may say more about those who express it that on the potential of this journalism. "Lowbrow" audiences can enjoy stories echoing their experiences, without condescension. And if the readership of more literary journalism is usually richer in cultural capital ...one of the trends of modernity is precisely the growing number of people reaching higher education. This more educated audience enjoys sophisticated narratives, concern for social issues. Many TV series produced by HBO (Game of Thrones...) have complex interwoven narrative structures, their collection of characters is much bigger that in the 60's series. Some (The Wire, The Newsroom) develop quasi-sociological explorations of social worlds.

They are complicated and long, they combine investigation and narrative. Could it be possible to see in such peculiarities a reason of -not a hindrance to- their success?

Erik Neveu

Professor of Political Science.

Centre de Recherche sur l'Action Politique en Europe. CNRS. Rennes.

erik.neveu@sciencespo-rennes.fr http://www.crape.univ-rennes 1.fr/membres/neveu_erik.htm 


\section{Notes}

1 Regional newspapers are cheaper. "Ouest-France" costs "only" 0,85 euros... still much more than Bild, Daily Mirror or the Norvegian VG.

2 Talese did it in his masterpiece portrayal of Sinatra ("Franck Sinatra has a cold") but after weeks of investigation and direct observation of his target.

3 The French word for someone with arabic ethnic origins.

\section{Bibliography}

Alexievitch, Svetlana. 1992. Zinky Boys. London: Chatto and Windus.

Aubenas, Florence. 2011. The Night Cleaner. London:Polity.

Bak, John and Reynolds, Bill; Eds. 2011. Literary Journalism Across the Globe: Journalistic Traditions and Transnational Influences. Amherst: University of Massachusetts Press.

Barnhurst, Kevin; and Nerone, John. 2002. The form of New. A History. New-York: Guilford Press.

Boynton, Robert. 2005. The New New Journalism. New-York : Vintage.

Brandewinder, Marie. 2009. Les consultants et le journalisme: le conseil médias dans les entreprises de presse. $\mathrm{Ph} \mathrm{D}$. Political Science. Université de Rennes.

Brin Colette. Charron Jean. and de Bonville Jean. 2004. Nature et transformations du Journalisme. Quebec : Presses de l'Université Laval.

Bourdieu, Pierre.1979 La Distinction. Paris: Minuit.

Broesma, Marcel, Ed. 2007. Form and Style in Journalism. European Newspapers and the representation of News 1880-2005. Louvain: Peeters.

Champagne, Patrick. 1993 La Vision médiatique, in Bourdieu, Pierre ; Ed. La misère du Monde, 61-79, Paris : Seuil.

Conover, Ted. 1987 Coyotes. New-York : Vintage.

Cook, Timothy. 1995. Governing with the news. The News Media as a political Institution. Chicago: Chicago University Press.

Darnton, Robert. 1975. "Writing News and Telling Stories."Daedalus, Vol 104(1): 175-194.

Downie, Leonard. and Schudson, Michael. 2009. "The Reconstruction of American Journalism." Columbia Journalism Review, http://www.journalism.columbia.edu/system/documents/1/original/Recon struction_of_Journalism.pdf

Eide, Martin \& Knight, Graham. 1999. "Public/Private Service. Service Journalism and the Problems of Everyday Life", European Journal of Communication, Vol 14(4): 525-547.

Hallin, Daniel. 1994. We Keep America on Top of The world, London: Routledge.

Harr, Jonathan. 1995. A Civil Action, New-York : Vintage.

Johnston, Jane and Graham, Caroline. 2012. "The New, Old Journalism. Narrative Writing in Contemporary Newspapers". Journalism Studies, Vol 13(1): 517-533.

Junger, Sebastian. 2010. War. New-York: Twelve.

Kovach, Bill and Rosenstiel, Tom. 2011. Blur: How to Know What's True in the Age of Information Overload. London: Bloomsbury. 
Leblanc, Adrian-Nicole. 2004. Random Family: Love, Drugs, Trouble, and Coming of Age in the Bronx. New-York: Scribner.

Machill, Marcel; Köhler, Sebastian and Waldhauser, Markus. 2007. "The Use of Narrative Structures in Television News." European Journal of Communication, Vol 22(2): 185-205.

Neveu, Erik. 2010, "News Without Journalists : Real Threat or Horror Story ?" Brasilian Journalism Review, Vol 6(1): 29-54.

Newman, Michael. 2010. "New Media, Young Audiences and Discourses of Attention." Media, Culture and Society, Vol 32(4):581-596.

Proust, Marcel. 1923. Pastiches et Mélanges. Paris : Gallimard.

Rébillard, Frank. 2006. "Du traitement de l'information à son retraitement. "Réseaux, $\mathrm{n}^{\circ} 137$ : 29-69.

Rieffel, Remy. 2010. Mythologie de la presse gratuite, Paris : Le cavalier Bleu.

Roy, Arundhati. 2011. Walking with the comrades. London : Penguin.

Ruffin, François. 2003. Les petits soldats $d u$ journalisme, Paris: Ed des Arènes.

Scherer. Michael. 2002. "Does Size Matter?" Columbia Journalism Review, Nov-Dec :32-36.

Schudson, Michael. 1982. "The Politics of Narrative Form: The Emergence of News Conventions in Print and Television", Daedalus, Vol 111(4): 97-112

Tunstall, Jeremy. 1971. Journalists at Work, London: Constable. 